\title{
Sexual dysfunction damages: A legal database review
}

Erin Jesse ${ }^{1}$; Wade Muncey ${ }^{1}$; Daniel Harris ${ }^{2}$; Kimberly Tay ${ }^{1}$; Tyler Kim²; Danly Omil-Lima ${ }^{2}$; Ilaha Isali ${ }^{1}$; Aram Loeb ${ }^{1}$; Nannan Thirumavalavan ${ }^{1}$

${ }^{1}$ Urology Institute, University Hospitals Cleveland Medical Center, Cleveland, OH, United States; ${ }^{2}$ Case Western Reserve University School of Medicine, Cleveland, OH, United States

Cite as: Jesse E, Muncey W, Harris D, et al. Sexual dysfunction damages: A legal database review. Can Urol Assoc J 2021 December 21; Epub ahead of print. http://dx.doi.org/10.5489/cuaj.7393

Published online December 21, 2021

Corresponding author: Dr. Wade Muncey, Urology Institute, University Hospitals Cleveland Medical Center, Cleveland, OH, United States; Wade.Muncey@UHhospitals.org

$* * *$

\section{Abstract}

Introduction: Procedural specialties are at higher risk for malpractice claims than nonprocedural specialties. Previous studies have examined common damages and malpractice lawsuits resulting from specific procedures. Our goal was to analyze urological interventions that led to sexual dysfunction claims.

Methods: The Casetext legal research platform was queried using search terms for medical malpractice and common men's health procedures between 1993 and 2020. In total, 236 cases were found and 21 cases met the inclusion criteria: malpractice cases against a urologist or urology group, clearly stated legal outcome, and allegation of sexual dysfunction from an intervention that directly caused damages.

Results: A total of 42 damages were cited in 21 lawsuits. The top three damages claimed were erectile dysfunction $(14 / 42,33.3 \%)$, genital pain syndrome $(7 / 42,16.7 \%)$, and urinary incontinence $(5 / 42,11.9 \%)$. The most commonly cited treatments were urinary catheter placement or removal $(3 / 21,14.3 \%)$, robotic-assisted laparoscopic radical prostatectomy (RALP) (3/21, 14.3\%), circumcision (3/21, 14.3\%), and penile implant (3/21, 14.3\%). In 19 of 21 suits $(90.4 \%)$, the outcome favored the defendant. Two cases favored the plaintiff: penile implant (failure to prove the patient was permanently, organically impotent prior to the procedure; $\$ 300000$ ) and vasectomy (damage to vasculature resulting in loss of testicle, $\$ 300$ 000).

Conclusions: Most suspected malpractice cases resulting in sexual dysfunction favored the defendant urologist. Interestingly, urinary catheter placement is as likely to result in litigation as other operative interventions, such as RALP, inflatable penile prosthesis, and circumcision. It is possible that thorough preoperative counselling and increased 
responsiveness to patients' postoperative concerns may have avoided litigation in several cases.

\section{Introduction}

Medical malpractice is defined as any deliberate act or negligence by a physician that deviates from the norms of practice established by the medical community during patient treatment and causes injury to a patient ${ }^{1}$. It is a subset of tort law that specializes in professional negligence and is a fundamental component of the current healthcare debate in the United States, influencing the current system's ever-increasing $\operatorname{cost}^{1-3}$. The risks inherent in surgery, the surgeon's exposure to risk, and subsequent insurance premiums are higher for surgeons than those of other doctors, and such costs can be significant for urologists ${ }^{4}$. National estimates of medical liability system costs, including settlements, legal and administrative expenses, and defense medicine, range from $\$ 55.6$ billion per year $(2.4 \%$ of total health expenditure) to $\$ 200$ billion per year ( $10 \%$ of healthcare spending $)^{5}$. Urology ranked eighth out of 25 specialties in the number of claims reported, and it was estimated that the average urologist would be sued at least twice in their career ${ }^{6}$. Although urologists often face lawsuits for surgical outcomes, overlooked diagnosis generally represents $15 \%$ of urological malpractice. These claims can have significant psychologic impacts for the physicians involved and even lead to decreased work productivity ${ }^{7-8}$.

Previous studies have examined common damages and litigation resulting from treatment of specific diseases and procedures ${ }^{9-10}$. One of the most common disease processes managed by urologists is sexual dysfunction (SD) ${ }^{11-12}$. Namely, SD is a disorder of sexual behavior and sexual sensation resulting from an abnormality or absence of sexual psychology and physiological reaction from which $52 \%$ of men between the ages of 40 and 70 suffer $^{13}$. SD can have significant impacts on a patient's quality of life ${ }^{14}$. Taking steps to minimize complications resulting in SD is therefore vital for patient care, and may also affect the chances of subsequent litigation. The goal of this study is to analyze urologic interventions that led to sexual dysfunction claims with the aim of identifying causative factors leading to these malpractice claims.

\section{Methods}

Casetext legal research platform was queried using search terms for medical malpractice and common men's health procedures between 1993-2020. Search for jury verdict reports was performed using the terms: "(medico-legal OR malpractice OR jurisprudence OR 'informed consent' OR negligence) AND ('sexual dysfunction' OR impotence OR 'erectile dysfunction' OR 'ejaculation dysfunction' OR infertility OR impotence OR hypogonadism OR ‘retrograde ejaculation’ OR anejaculation) AND (urology OR urologist)”. We defined sexual dysfunction damages in our study as any case that resulted in erectile dysfunction, genital pain syndrome, retrograde ejaculation, loss of a testicle, urinary incontinence, loss of genital sensation, or hypogonadism. Casetext provides unlimited access to a database of state and federal case summaries, statutes, federal regulations, and legal analyses. Inclusion criteria requirements were cases against a urologist or urologist group, some form of malpractice, 
clearly stated outcome favoring defendant or plaintiff, involvement of some form of sexual dysfunction in the damages, involvement of a treatment or procedure that allegedly directly caused damage(s), and damages occurring after 1980. The majority of studies were excluded based on a missed cancer diagnosis criterion, a lawsuit against a company, or a lawsuit not involving a urologist. The database is composed of coverage of all 50-state and federal cases, statutes, regulations, and rules. As the database only contains publicly available information, it was exempt from institutional review board review. Each case was evaluated for information regarding state of court, regional distribution of sexual dysfunction lawsuits, alleged breach of duty, alleged damages, treatments involved, circumstances regarding the case, legal outcome, and plaintiff awards.

\section{Results}

The initial search yielded 236 case texts written from 1993 to 2020. Only 21 met the inclusion criteria (Table 1A-1D). There were 42 damages cited in 21 lawsuits. The majority of sexual dysfunction lawsuits occurred in the Northeast (48\%) and Southeast (24\%), with other regions comprising the minority of cases (Midwest (14\%), Southwest (5\%), Northwest $(5 \%)$, and West $(5 \%))$. The areas of the body being treated or studied were also included (Table 2) and reported: prostate (33\%), penis (33\%), urethra (14\%), epididymis (10\%), vas deferens $(5 \%)$, and inguinal region $(5 \%)$. As for the specific causes of malpractice, the most common breach of duty (Table 3) was deviation from standard of care resulting in damage (31\%). Procedural error $(25 \%)$, negligence (18\%), failure to achieve informed consent $(6 \%)$, overtreatment $(6 \%)$, failure to disclose information $(6 \%)$, and deliberate indifference to medical needs $(6 \%)$ were other alleged breaches of duties. The most common damages were erectile dysfunction (33\%), genital pain syndrome (17\%), and urinary incontinence $(12 \%)$. Other damages included sexual dysfunction (7\%), difficulty with urination (5\%), other urinary symptoms $(5 \%)$, failed penile implant $(5 \%)$, loss of sensation of genitals $(5 \%)$, loss of a testicle $(5 \%)$, hypogonadism $(2 \%)$, urethral laceration $(2 \%)$, and retrograde ejaculation $(2 \%)$.

In total, 21 procedures or treatments were documented and the most commonly cited were urinary catheter placement or removal (14\%), RALP (14\%), insertion of inflatable penile prosthesis (IPP) (14\%), and circumcision (14\%). Additional procedures included transurethral resection of the prostate (TURP) (10\%), epididymectomy (10\%), prostiva procedure (5\%), photoselective vaporization of prostate (PVP) $(5 \%)$, inguinal hernia repair $(5) \%$, vasectomy (5\%), and penile skin debridement (5\%). The average time between damage and court appearance was found to be 5 years.

We also categorized the findings by defendant type. While a single urologist was named as a defendant in all cases, additional defendants included urology groups in 2 cases, United States Department of Veterans Affairs in 2 cases, a urology nurse in one case, a urology resident in 1 case, and a correctional institute in 1 case. The defendant urologist personally performed the procedure in the majority of cases, however, a urology nurse performed a removal of catheter in one case, and a urology resident performed a circumcision under the supervision of the urologist in another case. In 19 of the 21 suits $(90.4 \%)$, the outcome favored the defendant urologist. Only 2 suits $(9.5 \%, 95 \%$ CI $[0.0,22.1])$ concluded 
with an indemnity payment favoring plaintiff with payment awarded by verdict: penile implant (failure to disclose prove the patient would be permanently, organically impotent prior to the procedure; missed urethral injury at time of surgery; $\$ 300,000$ ) and vasectomy (damage to vasculature resulting in loss of testicle, $\$ 300,000$ ).

\section{Discussion}

The current study analyzed urologic interventions that led to sexual dysfunction claims and found that most of the suspected cases of malpractice that lead to sexual dysfunction were ruled in favor of the defendant urologist. In a many of these cases, review of the medical records by the judge or testimony given by expert witnesses (typically other practicing urologists) was sufficient to show that the defendant urologist did not deviate from the standard of care, and thus the court ruled in favor of the urologist. This highlights the that keeping detailed and accurate office and procedural notes may aid in protection against litigation.

The most commonly claimed damage was erectile dysfunction. Erectile dysfunction is a frequently encountered disease in urologic practice and is a particularly troubling consequence of several common urology procedures. For example, the reported incidence of erectile dysfunction following radical prostatectomy can be as high as $85 \%$ and following TURP can be as high as $14 \%{ }^{15-16}$. In one case involving an erectile dysfunction claim after RALP (Lucsik v. Kosdrosky), the court favored the defendant urologist because it was highlighted by expert witnesses that ED is a known possible outcome RALP, the urologist appropriately counseled the patient on this pre-operatively, and the urologist was otherwise found not to deviate from the standard of care. This case highlights the fact that patient counseling remains a critical part of the preoperative shared decision making process, which may help to avoid patient dissatisfaction regarding their $\mathrm{ED}^{17}$. In addition, thorough documentation of these conversations and informed consent prior to the procedure may also aid in protection of the urologist during litigation.

Among the 14 cases involving claims of erectile dysfunction, only one favored the plaintiff, resulting in an indemnity payment awarded by the verdict. This was Bailey v. Emiliio, a case involving the insertion of an IPP by a single urologist. The patient claimed his physician did not complete a thorough workup for his ED to ascertain whether he was permanently impotent prior to proceeding with the penile implant, nor was he counseled that the placement of a penile implant would leave him irreversibly impotent should the device be removed. At the time of implantation, a urethral injury occurred and was not detected by the urologist. This resulted in the patient having urine extravasation and severe genital pain and swelling, ultimately requiring an explant of his prosthesis and urethral repair by a separate urologist. The plaintiff's expert witnesses claimed that the patient's diabetes and/or depression could have been reversible causes of his ED. In addition, the defendant gave the plaintiff a "snap gauge" to test for nighttime erection at his first visit, and the plaintiff states he did obtain an erection causing one of the bands to break one night pre-operatively. The jury found that this was sufficient evidence to conclude that the defendant failed to prove the plaintiff was permanently impotent prior to surgery. The court documents also demonstrate 
that the physician did not appear responsive to the patient's postoperative concerns and discomfort after surgery. For example, when the patient presented back with complaints of intense pain in his genitals and urinary retention/overflow incontinence, he was advised to begin catheterizing himself without further investigation. These cases highlight that when an operative complication goes unrecognized, dismissiveness of patient concern in the postoperative period may contribute to a patient's decision to pursue litigation. Ultimately, the plaintiff was awarded noneconomic damages of $\$ 300,000$.

We also found several cases involving claims of erectile dysfunction that were deemed by the court to not be the direct result of the procedure performed by the urologist. These examples include a painful removal of a foley catheter (Parker v. Tomera), repeated catheterization (Reilly v. Spinazze), an accidental pulling of foley catheter tubing (Ward v. Marymount Hospital), a malfunction of the Da Vinci robot during RALP (Mracek v. Bryn Mawr Hospital), post-operative swelling following circumcision (Collado v. Plawner), an epididymectomy (Bellamy v. Mount Vernon Hospital), and an inguinal hernia repair (Aidnik v. California Department of Corrections). In many of these cases, review of the medical record and expert testimony were once again key in the court's decision. While none of these cases resulted in an indemnity payment to the plaintiff, they do highlight the importance of consistent patient education and expectation management. In such cases that do not involve technical failure by the urologist, several published strategies for minimizing malpractice lawsuits may apply. These include establishing trusting and open relationships with patients, objectively conveying the risks and benefits of proposed medical procedures, and offering a second opinion when a patient is unsure of a treatment course. ${ }^{20-21}$

Our study showed that procedural error and deviation from the standard of care resulting in damages were the most commonly cited breaches of duty, and this finding mirrored other published reports evaluating general urology claims. ${ }^{18}$ Despite this finding, several cases might have been avoided had there been a discussion of possible risks inherent to a procedure. For example, in the instance of Michtavi v. Scism in 2013, the Plaintiff alleged that following photoselective vaporization of the prostate (PVP) the physician "caused the Plaintiff's sperm to leak into his bladder." Retrograde ejaculation is a known side effect of PVP, and this case demonstrates how clear communication regarding possible adverse events at the time of, or following, surgery may decrease litigation. ${ }^{19}$

Our legal database review can be helpful to urologists who wish to learn about the circumstances that may lead to litigation involving sexual dysfunction claims, the reasons why a urologist may or may not be favored by the jury, and what steps may be taken by a urologist to prevent or protect themselves from such litigation. However, our study is not without significant limitations. Namely, there is no single national repository of malpractice claims from which to review all possible cases, and $90 \%$ of cases are settle prior to trial, ${ }^{22}$ greatly limiting the number of cases that are available for review. Within Casetext, different jurisdictions have varied reporting requirements, leading to incomplete data capture among the documents, and a considerable number of cases that had to be excluded. Also, several of the cases were reversed and remanded for a retrial, but the information regarding these retrials is not available, possibly leading to an incomplete picture of the overall case in our 
data collection. Finally, the documents available on Casetext are legal text, not medical text. As such, there are many details such as preoperative planning and decision making, intraoperative reports, and subsequent physician documentation that are not available for our review. Such information may have added to the potential for urologists to learn from this review.

All physicians are inevitably subjected to medical litigation or misapplication cases at least once in their career ${ }^{23}$. Regardless of the outcome of the case in question, it is important that information on such disputes and litigation is made available to the medical community from which to learn and help prevent further disputes and misconduct, and ultimately improve patient care.

\section{Conclusions}

The majority of suspected malpractice cases resulting in sexual dysfunction favored the defendant urologist. Procedural error and deviation from the standard of care resulting in damages were the most commonly cited allegations, but thorough preoperative counseling and taking patient's post-operative complaints seriously may have avoided litigation in several cases. Keeping thorough records and procedural notes that document standard of care practices can aid urologists in having a successful defense in the event that they face litigation. It is important for physicians to gain an understanding of such medical malpractice claims and their outcomes, as this may aid in prevention of future litigation and ultimately improve patient care.

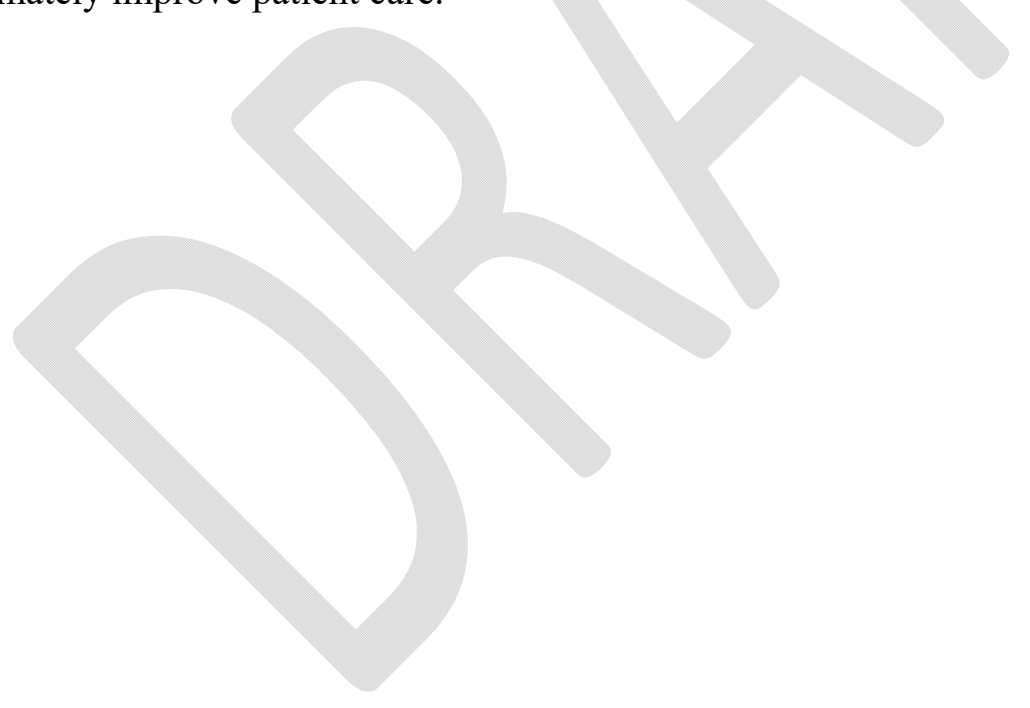




\section{References}

1. Bal BS. An introduction to medical malpractice in the United States. Clin Orthop Relat Res 2009;467:339-47.

2. Rothstein MA. Currents in contemporary bioethics. Health care reform and medical malpractice claims. J Law Med Ethics 2010;38:871-4.

3. Frakes M, Jena AB. Does medical malpractice law improve health care quality? $J$ Public Econ 2016;143:142-58.

4. Alemzadeh H, Raman J, Leveson N, et al. Adverse events in robotic surgery: A retrospective study of 14 years of FDA data. PLoS One 2016;11:e0151470.

5. Zuckerman S. Medical malpractice: Claims, legal costs, and the practice of defensive medicine, Health Aff 1984:3;128-33.

6. Franc-Guimond J, Mcneil B, Schlossberg SM, et al. Urologist burnout: Frequency, causes, and potential solutions to an unspoken entity. Can Urol Assoc J 2018;12:13742.

7. Kahan SE, Goldman HB, Marengo S, et al. Urological medical malpractice. J Urol 2001;165:1638-42.

8. Patel RS, Bachu R, Adikey A, et al. Factors related to physician burnout and its consequences: A review. Behav Sci (Basel) 2018;8:98.

9. Somville FJ, van Sprundel M, Somville J. Analysis of surgical errors in malpractice claims in Belgium. Acta Chir Belg 2010;110:11-8.

10. Jiam NT, Cooper MA, Lyu HG, et al. Surgical malpractice claims in the United States. J Healthc Risk Manag 2014;33:29-34.

11. Camacho ME, Reyes-Ortiz CA. Sexual dysfunction in the elderly: age or disease?. Int J Impot Res 2005;17:S52-6.

12. Gareri P, Castagna A, Francomano D, et al. Erectile dysfunction in the elderly: An old widespread issue with novel treatment perspectives. Int J Endocrinol 2014;2014:878670.

13. Chen L, Shi GR, Huang DD, et al. Male sexual dysfunction: A review of literature on its pathological mechanisms, potential risk factors, and herbal drug intervention. Biomed Pharmacother 2019;112:108585.

14. Prabhu V, Lee T, McClintock TR, et al. Short-, intermediate-, and long-term quality of life outcomes following radical prostatectomy for clinically localized prostate cancer. Rev Urol 2013;15:161-77.

15. Emanu JC, Avildsen IK, Nelson CJ. Erectile dysfunction after radical prostatectomy: Prevalence, medical treatments, and psychosocial interventions. Curr Opin Support Palliat Care 2016;10:102-7.

16. Castiglione F, Ralph DJ, Muneer A. Surgical techniques for managing postprostatectomy erectile dysfunction. Curr Urol Rep. 2017;18:90.

17. Doğan Ç, Gültekin HM, Erdoğan SM, et al. Patient decision making prior to radical prostatectomy: What is and is not involved. Am J Mens Health 2017;11:108-15.

18. Sherer BA, Boydston KC, Coogan CL. Urological malpractice: Claim trend analysis and severity of injury, Urology Practice 2016;3:443-8.

19. Payne VL, Singh H, Meyer AN, et al. Patient-initiated second opinions: systematic review of characteristics and impact on diagnosis, treatment, and satisfaction. Mayo Clin Proc 2014;89:687-96.

20. Chao TC. Medical negligence--prevention and management. Ann Acad Med Singap 1987;16:371-4. 
21. Raveesh BN, Nayak RB, Kumbar SF. Preventing medico-legal issues in clinical practice. Ann Indian Acad Neurol 2016;19:S15-S20.

22. Canady MR. The verdict is in: Surviving a medical malpractice trial. Physician Leadersh J 2016;3:14-7.

23. Upadhyay A, York S, Macaulay W, et al. Medical malpractice in hip and knee arthroplasty. J Arthroplasty 2007;22:2-7. 


\section{Figures and Tables}

\begin{tabular}{|c|c|c|c|c|c|}
\hline \multicolumn{6}{|c|}{ Table 1A. Description of cases in the study } \\
\hline Case title & Case summary & $\begin{array}{l}\text { Alleged } \\
\text { breach(es) of } \\
\text { duty }\end{array}$ & $\begin{array}{l}\text { Alleged } \\
\text { damage(s) }\end{array}$ & $\begin{array}{l}\text { Legal } \\
\text { outcome }\end{array}$ & Outcome summary \\
\hline \multicolumn{6}{|c|}{ Foley catheter placement/removal } \\
\hline Parker v. Tomera ${ }^{\mathrm{A}}$ & $\begin{array}{l}\text { An RN performed in-office Parson's test under } \\
\text { direction of urologist. Plaintiff claimed RN removed } \\
\text { catheter quickly and traumatically, causing pain and } \\
\text { ultimately sexual dysfunction, thus claiming the } \\
\text { catheterization was performed negligently. Plaintiff } \\
\text { also alleged there was failure to obtain informed } \\
\text { consent. }\end{array}$ & $\begin{array}{l}\text { Failure to } \\
\text { achieve } \\
\text { informed } \\
\text { consent, } \\
\text { negligence }\end{array}$ & \begin{tabular}{|l|} 
Sexual \\
dysfunction, \\
erectile \\
dysfunction
\end{tabular} & $\begin{array}{l}\text { Favoring } \\
\text { defense }\end{array}$ & $\begin{array}{l}\text { Expert testimony } \\
\text { asserted that the } \\
\text { procedure could not } \\
\text { have resulted in such } \\
\text { damages. Plaintiff } \\
\text { unable to prove his } \\
\text { claim. }\end{array}$ \\
\hline Reilly v. Spinazze ${ }^{\mathrm{B}}$ & $\begin{array}{l}\text { Plaintiff suffered severe pelvic injury after a horse } \\
\text { fell on him at work. The defendant urologist was } \\
\text { ultimately consulted for hematuria, which was } \\
\text { managed with a cystogram and several days } \\
\text { duration of catheter. Plaintiff failed trial of void and } \\
\text { was diagnosed with a bulbar stricture. Plaintiff } \\
\text { claims several traumatic catheter placements and } \\
\text { removals were performed negligently, causing } \\
\text { impotence. }\end{array}$ & $\begin{array}{l}\text { Deviation } \\
\text { from } \\
\text { standard of } \\
\text { care resulting } \\
\text { in damage, } \\
\text { negligence }\end{array}$ & \begin{tabular}{|l} 
Erectile \\
dysfunction, \\
urinary \\
incontinence
\end{tabular} & $\begin{array}{l}\text { Favoring } \\
\text { defense }\end{array}$ & $\begin{array}{l}\text { A medical review } \\
\text { panel found that the } \\
\text { defendant met the } \\
\text { standard or care and } \\
\text { concluded the } \\
\text { plaintiff's impotence } \\
\text { was more likely } \\
\text { secondary to his } \\
\text { initial trauma. }\end{array}$ \\
\hline $\begin{array}{l}\text { Ward v. Marymount } \\
\text { Hospital }^{\mathrm{C}}\end{array}$ & $\begin{array}{l}\text { Plaintiff underwent a colorectal surgery; the } \\
\text { defendant urologist was involved by placing ureteral } \\
\text { stents. Post-operatively, a nurse tripped over } \\
\text { Plaintiff's foley catheter tubing, causing extreme } \\
\text { pain. Plaintiff was ultimately diagnosed with a } \\
\text { neurogenic bladder and impotence. Plaintiff alleges } \\
\text { that the defendant should have seen the catheter }\end{array}$ & $\begin{array}{l}\text { Negligence, } \\
\text { deviation } \\
\text { from } \\
\text { standard of } \\
\text { care resulting } \\
\text { in damage }\end{array}$ & $\begin{array}{l}\text { Erectile } \\
\text { dysfunction, } \\
\text { difficulty } \\
\text { with } \\
\text { urination }\end{array}$ & $\begin{array}{l}\text { Favoring } \\
\text { defense, but } \\
\text { reversed and } \\
\text { remanded } \\
\text { for further } \\
\text { prorceadinigs }\end{array}$ & $\begin{array}{l}\text { The trial judge } \\
\text { initially ruled in } \\
\text { favor of the defense } \\
\text { prior to trail, opining } \\
\text { that there was no } \\
\text { relwiglearlesøfiation } \\
\text { misconduct on }\end{array}$ \\
\hline
\end{tabular}




\begin{tabular}{|c|c|c|c|c|c|}
\hline & $\begin{array}{l}\text { tubing on the floor, and thus he failed to remedy the } \\
\text { dangerous situation. He claimed his inability to } \\
\text { urinate and impotence was a direct consequence of } \\
\text { the incident. }\end{array}$ & & & & $\begin{array}{l}\text { initial review. } \\
\text { However, the } \\
\text { plaintiff appealed } \\
\text { this and argued that } \\
\text { he intended to prove } \\
\text { the defendant's } \\
\text { negligence to the } \\
\text { jury. The claim } \\
\text { against the } \\
\text { defendant was } \\
\text { remanded for further } \\
\text { proceedings. Further } \\
\text { information on these } \\
\text { proceedings } \\
\text { unavailable. }\end{array}$ \\
\hline \multicolumn{6}{|c|}{ Transurethral resection of prostate } \\
\hline Hager v. Shanm-ugham ${ }^{\mathrm{D}}$ & $\begin{array}{l}\text { Plaintiff underwent TURP and subsequently } \\
\text { developed urinary incontinence and impotence. He } \\
\text { claimed the defendant deviated from the standard of } \\
\text { care and negligently performed the procedure. }\end{array}$ & $\begin{array}{l}\text { Procedural } \\
\text { error, } \\
\text { deviation } \\
\text { from } \\
\text { standard of } \\
\text { care resulting } \\
\text { in damage, } \\
\text { overtreatment }\end{array}$ & $\begin{array}{l}\text { Urinary } \\
\text { incontinence, } \\
\text { erectile } \\
\text { dysfunction }\end{array}$ & $\begin{array}{l}\text { Favoring } \\
\text { defense }\end{array}$ & $\begin{array}{l}\text { An expert witness } \\
\text { testified that injury } \\
\text { to the external } \\
\text { urinary sphincter } \\
\text { resulting in } \\
\text { incontinence was a } \\
\text { recognized } \\
\text { complication of the } \\
\text { procedure that can } \\
\text { occur in the absence } \\
\text { of negligence by the } \\
\text { surgeon. }\end{array}$ \\
\hline
\end{tabular}




\begin{tabular}{|c|c|c|c|c|c|}
\hline Turner v. Lopez ${ }^{\mathrm{E}}$ & $\begin{array}{l}\text { Plaintiff underwent TURP and alleged that the } \\
\text { procedure caused urinary incontinence and erectile } \\
\text { dysfunction, and claimed that the defendant acted } \\
\text { with "deliberate indifference" toward these medical } \\
\text { issues. }\end{array}$ & $\begin{array}{l}\text { Procedural } \\
\text { error, } \\
\text { deviation } \\
\text { from } \\
\text { standard of } \\
\text { care resulting } \\
\text { in damage, } \\
\text { deliberate } \\
\text { indifference } \\
\text { to medical } \\
\text { needs }\end{array}$ & $\begin{array}{l}\text { Erectile } \\
\text { dysfunction, } \\
\text { urinary } \\
\text { incontinence }\end{array}$ & $\begin{array}{l}\text { Defendant's } \\
\text { motion to } \\
\text { dismiss was } \\
\text { granted }\end{array}$ & $\begin{array}{l}\text { Due to plaintiff's } \\
\text { "failure to oppose } \\
\text { the motion to } \\
\text { dismiss, his failure } \\
\text { to prosecute the } \\
\text { case, and his failure } \\
\text { to file... a certificate } \\
\text { of merit to support } \\
\text { his negligence } \\
\text { claims" the case was } \\
\text { dismissed. }\end{array}$ \\
\hline \multicolumn{6}{|l|}{ Prostiva procedure } \\
\hline Douglas v. Lanier ${ }^{\mathrm{F}}$ & $\begin{array}{l}\text { Plaintiff suffered from retrograde ejaculation } \\
\text { following Prostiva procedure, and states the } \\
\text { defendant, "was not entirely truthful" when he said } \\
\text { the procedure was safe and that he would not suffer } \\
\text { from any "erectile or genital related difficulties". }\end{array}$ & $\begin{array}{l}\text { Procedural } \\
\text { error, } \\
\text { deviation } \\
\text { from } \\
\text { standard of } \\
\text { care resulting } \\
\text { in damage, } \\
\text { failure to } \\
\text { disclose } \\
\text { information }\end{array}$ & $\begin{array}{l}\text { Erectile } \\
\text { dysfunction }\end{array}$ & $\begin{array}{l}\text { Action } \\
\text { against the } \\
\text { defendant } \\
\text { was } \\
\text { dismissed } \\
\text { prior to trial. }\end{array}$ & $\begin{array}{l}\text { The plaintiff was } \\
\text { unable to provide } \\
\text { sufficient } \\
\text { information (a } \\
\text { correct mailing } \\
\text { address) for the } \\
\text { Marshal to serve the } \\
\text { defendant. }\end{array}$ \\
\hline \multicolumn{6}{|c|}{ Photoselective vaporization of the prostate (PVP) } \\
\hline Michtavi v. Scism ${ }^{\mathrm{G}}$ & $\begin{array}{l}\text { Plaintiff claimed that the defendant negligently } \\
\text { performed a procedure on his prostate "which } \\
\text { caused Plaintiff's sperm to leak into his bladder (i.e., } \\
\text { retrograde ejaculation)." }\end{array}$ & $\begin{array}{l}\text { Negligence, } \\
\text { procedural } \\
\text { error, } \\
\text { deviation } \\
\text { from } \\
\text { standard of } \\
\text { care resulting } \\
\text { in damage }\end{array}$ & $\begin{array}{l}\text { Erectile } \\
\text { dysfunction, } \\
\text { retrograde } \\
\text { ejaculation }\end{array}$ & $\begin{array}{l}\text { Action } \\
\text { against the } \\
\text { defendant } \\
\text { was } \\
\text { dismissed } \\
\text { prior to trial. }\end{array}$ & $\begin{array}{l}\text { The plaintiff was } \\
\text { incarcerated, and he } \\
\text { presented Bivens } \\
\text { claims (i.e., claims } \\
\text { against a federal } \\
\text { officer). As the } \\
\text { defendant was a } \\
\text { private urologist, the }\end{array}$ \\
\hline
\end{tabular}




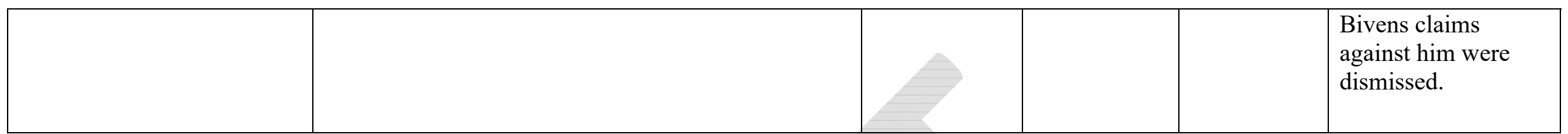

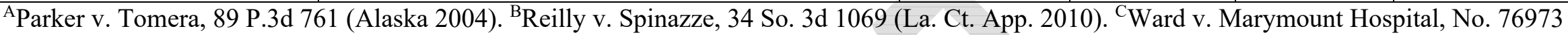
(Ohio Ct. App. Oct. 12, 2000). ${ }^{\text {D} H a g e r ~ v . ~ S h a n m u g h a m, ~} 190$ W. Va. 703 (W. Va. 1993). ${ }^{E}$ Turner v. Lopez, CIVIL ACTION No. 3:13-872 (M.D. Pa. Dec. 9, 2013). ${ }^{\mathrm{F}}$ Douglas v. Lanier, CIVIL No. 1:12-CV-0340 (M.D. Pa. Sep. 11, 2013). ${ }^{\mathrm{G}}$ Michtavi v. Scism, 808 F.3d 203 (3d Cir. 2015)

\begin{tabular}{|c|c|c|c|c|c|}
\hline \multicolumn{6}{|c|}{ Table 1B. Description of cases in the study } \\
\hline Case title & Case summary & $\begin{array}{l}\text { Alleged } \\
\text { breach(es) of } \\
\text { duty }\end{array}$ & $\begin{array}{l}\text { Alleged } \\
\text { damage(s) }\end{array}$ & Legalo & $\begin{array}{l}\text { Outcome } \\
\text { summary }\end{array}$ \\
\hline \multicolumn{6}{|c|}{ Robotic-assisted laparoscopic radical prostatectomy (RALP) } \\
\hline Lucsik v. Kosdrosky ${ }^{\mathrm{H}}$ & $\begin{array}{l}\text { Plaintiff claimed that the defendant was negligent } \\
\text { in performing surgery for the patient's } \\
\text { intermediate risk prostate cancer. The plaintiff } \\
\text { alleged negligence "by not opting for less risky } \\
\text { treatment options", and claims "pain, permanent } \\
\text { urinary incontinence, permanent sexual } \\
\text { dysfunction, and permanent loss of bladder } \\
\text { control" as a result. }\end{array}$ & $\begin{array}{l}\text { Overtreatment, } \\
\text { deviation from } \\
\text { standard of } \\
\text { care }\end{array}$ & $\begin{array}{l}\text { Genital pain } \\
\text { syndrome, } \\
\text { sexual } \\
\text { dysfunction, } \\
\text { urinary } \\
\text { incontinence }\end{array}$ & $\begin{array}{l}\text { Favoring } \\
\text { defense }\end{array}$ & $\begin{array}{l}\text { An expert witness } \\
\text { testified that the } \\
\text { defendant met the } \\
\text { standard of care } \\
\text { in the treatment of } \\
\text { the plaintiff, and a } \\
\text { jury trial resulted } \\
\text { in a defense } \\
\text { verdict. }\end{array}$ \\
\hline $\begin{array}{l}\text { Mracek v. Bryn Mawr } \\
\text { Hospital }^{I}\end{array}$ & $\begin{array}{l}\text { Plaintiff underwent RALP during which a } \\
\text { technical malfunction of the Da Vinci robot } \\
\text { ultimately required the defended urologist to abort } \\
\text { the robotic approach and finish the procedure } \\
\text { laparoscopically. Plaintiff subsequently suffered } \\
\text { from erectile dysfunction, and "claimed that the } \\
\text { robot malfunction was the direct cause of his }\end{array}$ & $\begin{array}{l}\text { Procedural } \\
\text { error, deviation } \\
\text { from standard } \\
\text { of care, } \\
\text { negligence }\end{array}$ & $\begin{array}{l}\text { Erectile } \\
\text { dysfunction }\end{array}$ & $\begin{array}{l}\text { Favoring } \\
\text { defense }\end{array}$ & $\begin{array}{l}\text { Plaintiff was } \\
\text { unable to produce } \\
\text { direct evidence of } \\
\text { causation to } \\
\text { support his claim. }\end{array}$ \\
\hline
\end{tabular}




\begin{tabular}{|c|c|c|c|c|c|}
\hline & erectile dysfunction." & & & & \\
\hline Teixeira v. Bhalla ${ }^{\mathrm{J}}$ & $\begin{array}{l}\text { Plaintiff underwent RALP and subsequently } \\
\text { developed erectile dysfunction and difficulty with } \\
\text { urination. He claimed he was not properly } \\
\text { informed of the risk of erectile dysfunction prior } \\
\text { to the procedure. Several years later, his treating } \\
\text { urologist identified a "Hem-O-Lok Clip" within } \\
\text { his bladder. Plaintiff claimed negligence of the } \\
\text { defendant in leaving behind a foreign body. }\end{array}$ & $\begin{array}{l}\text { Failure to } \\
\text { achieve } \\
\text { informed } \\
\text { consent, } \\
\text { procedural } \\
\text { error, } \\
\text { negligence }\end{array}$ & $\begin{array}{l}\text { Erectile } \\
\text { dysfunction, } \\
\text { difficulty } \\
\text { with } \\
\text { urination }\end{array}$ & $\begin{array}{l}\text { Favoring } \\
\text { defense }\end{array}$ & $\begin{array}{l}\text { The clip was } \\
\text { deemed not to be } \\
\text { a foreign body as } \\
\text { it was placed } \\
\text { intentionally. } \\
\text { Expert witnesses } \\
\text { testified that the } \\
\text { clip likely } \\
\text { migrated. The rest } \\
\text { of the claims were } \\
\text { dismissed under } \\
\text { the statute of } \\
\text { limitations. }\end{array}$ \\
\hline \multicolumn{6}{|c|}{ Insertion of penile prosthesis (IPP) } \\
\hline $\begin{array}{l}\text { Bailey v. Emiliio C. Chu, } \\
\text { M.D., Inc. }{ }^{\mathrm{K}}\end{array}$ & $\begin{array}{l}\text { Plaintiff suffered a urethral injury that was missed } \\
\text { by the surgeon during the insertion of IPP, and he } \\
\text { required subsequent excision of penile implant } \\
\text { and urethral repair by a separate urologist. } \\
\text { Plaintiff claimed the defendant did not meet the } \\
\text { standard of care by failing to prove he was } \\
\text { "permanently, organically impotent prior to } \\
\text { proceeding with the penile implant", and claimed } \\
\text { a different, less invasive treatment may have been } \\
\text { successful in treating his ED. In addition, he } \\
\text { claimed negligence of the defendant in failing to } \\
\text { detect the urethral injury at the time of surgery or } \\
\text { in a timely fashion post-operatively. }\end{array}$ & $\begin{array}{l}\text { Overtreatment, } \\
\text { failure to } \\
\text { disclose } \\
\text { information, } \\
\text { negligence }\end{array}$ & $\begin{array}{l}\text { Genital pain } \\
\text { syndrome, } \\
\text { urinary } \\
\text { incontinence, } \\
\text { urethral } \\
\text { laceration, } \\
\text { erectile } \\
\text { dysfunction }\end{array}$ & $\begin{array}{l}\text { Favoring } \\
\text { plaintiff }\end{array}$ & $\begin{array}{l}\text { The plaintiff's } \\
\text { expert witnesses } \\
\text { claimed that the } \\
\text { patient's diabetes } \\
\text { and/or depression } \\
\text { could have been } \\
\text { reversible causes } \\
\text { of his ED. In } \\
\text { addition, the } \\
\text { defendant gave } \\
\text { the plaintiff a } \\
\text { "snap gauge" at a } \\
\text { visit, and the } \\
\text { plaintiff states he } \\
\text { did obtain an } \\
\text { erection causing }\end{array}$ \\
\hline
\end{tabular}




\begin{tabular}{|c|c|c|c|c|c|}
\hline & & & & & $\begin{array}{l}\text { one of the bands } \\
\text { to break one } \\
\text { night. The jury } \\
\text { found that this } \\
\text { was sufficient } \\
\text { evidence to } \\
\text { conclude that the } \\
\text { defendant failed } \\
\text { to prove the } \\
\text { plaintiff was } \\
\text { permanently } \\
\text { impotent prior to } \\
\text { surgery. Plaintiff } \\
\text { was awarded } \\
\text { damages of } \\
\$ 300,000 \text {. }\end{array}$ \\
\hline Gautieri v. United States ${ }^{\mathrm{L}}$ & $\begin{array}{l}\text { Plaintiff suffered from a "bulge on the left side of } \\
\text { his penis" associated with pain after undergoing } \\
\text { insertion of IPP, and ultimately underwent } \\
\text { excision of the implant. Plaintiff alleged that the } \\
\text { defendant did not meet standard of care during } \\
\text { surgery or in his post-operative care. }\end{array}$ & $\begin{array}{l}\text { Procedural } \\
\text { error, deviation } \\
\text { from standard } \\
\text { of care }\end{array}$ & $\begin{array}{l}\text { Genital Pain } \\
\text { syndrome, } \\
\text { failed penile } \\
\text { implant }\end{array}$ & $\begin{array}{l}\text { Favoring } \\
\text { defense }\end{array}$ & $\begin{array}{l}\text { Plaintiff failed to } \\
\text { establish any } \\
\text { deviation from } \\
\text { the standard of } \\
\text { care through } \\
\text { review of the } \\
\text { operative report } \\
\text { and expert } \\
\text { testimony. }\end{array}$ \\
\hline Day v. Morrison ${ }^{\mathrm{M}}$ & $\begin{array}{l}\text { Plaintiff was diagnosed with cylinder crossover } \\
\text { post-operatively and ultimately underwent two } \\
\text { surgical revisions by a separate urologist. Plaintiff } \\
\text { claimed the defendant was negligent and } \\
\text { "exercised minimal surgical competence in } \\
\text { performing" the initial procedure. }\end{array}$ & $\begin{array}{l}\text { Procedural } \\
\text { error, deviation } \\
\text { from standard } \\
\text { of care, } \\
\text { negligence }\end{array}$ & $\begin{array}{l}\text { Genital Pain } \\
\text { syndrome, } \\
\text { failed penile } \\
\text { implant }\end{array}$ & $\begin{array}{l}\text { Favoring } \\
\text { defense, but } \\
\text { reversed and } \\
\text { remanded for } \\
\text { a retrial }\end{array}$ & $\begin{array}{l}\text { The jury's verdict } \\
\text { was in favor of } \\
\text { the defense, } \\
\text { however, on } \\
\text { appeal it was } \\
\text { found "that the }\end{array}$ \\
\hline
\end{tabular}




\begin{tabular}{|c|c|c|c|c|c|}
\hline & & & & & $\begin{array}{l}\text { jury was } \\
\text { improperly } \\
\text { instructed" that "a } \\
\text { competent } \\
\text { physician is not } \\
\text { liable per se for a } \\
\text { mere error of } \\
\text { judgment". It was } \\
\text { determined that } \\
\text { this language may } \\
\text { be confusing to a } \\
\text { jury and, as such, } \\
\text { a retrial was } \\
\text { granted. } \\
\text { Information on } \\
\text { the retrial is not } \\
\text { available. }\end{array}$ \\
\hline \multicolumn{6}{|l|}{ Inguinal hernia repair } \\
\hline $\begin{array}{l}\text { Aidnik v. California Dept } \\
\text { of Corrections }{ }^{\mathrm{N}}\end{array}$ & $\begin{array}{l}\text { Plaintiff presented to the defendant with } \\
\text { complaints of a recurrent inguinal hernia causing } \\
\text { significant pain. He elected to undergo repair of } \\
\text { the hernia. He was counseled that repair did not } \\
\text { guarantee resolution of the pain. Post-operatively, } \\
\text { he complained of pain, a lack of feeling in his } \\
\text { right testicle, and erectile dysfunction. He alleged } \\
\text { that the defendant acted with deliberate } \\
\text { indifference to the patient's post-operative medical } \\
\text { issues. }\end{array}$ & $\begin{array}{l}\text { Procedural } \\
\text { error, deviation } \\
\text { from standard } \\
\text { of } \\
\text { care, deliberate } \\
\text { indifference }\end{array}$ & $\begin{array}{l}\text { Erectile } \\
\text { dysfunction, } \\
\text { other urinary } \\
\text { symptoms }\end{array}$ & $\begin{array}{l}\text { Favoring } \\
\text { defense; } \\
\text { summary } \\
\text { judgement } \\
\text { granted to } \\
\text { defendant on } \\
\text { all claims. }\end{array}$ & $\begin{array}{l}\text { Review of the } \\
\text { medical record } \\
\text { showed no } \\
\text { evidence of } \\
\text { deliberate } \\
\text { indifference by } \\
\text { the defendant and } \\
\text { no evidence of } \\
\text { refusal to treat the } \\
\text { plaintiff post- } \\
\text { operatively. }\end{array}$ \\
\hline
\end{tabular}

${ }^{\mathrm{H}}$ Lucsik v. Kosdrosky, 79 N.E.3d 1284 (Ohio Ct. App. 2017). ${ }^{\mathrm{I}}$ Mracek v. Bryn Mawr Hospital, 610 F. Supp. 2d 401 (E.D. Pa. 2009). ${ }^{\mathrm{J}}$ Teixeira

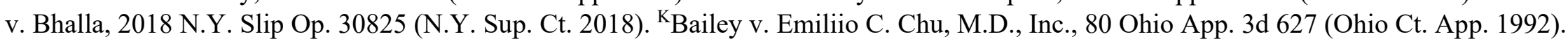


${ }^{\mathrm{L}}$ Gautieri v. U.S., C.A. No. 00-053-L (D.R.I. Sep. 19, 2001). ${ }^{\mathrm{M}}$ Day v. Morrison, 657 So. 2d 808 (Miss. 1995). ${ }^{\text {N} A i d n i k ~ v . ~ C a l i f o r n i a ~ D e p a r t m e n t ~}$ of Corrections, No. CIV S-09-0154 KJM P

\begin{tabular}{|c|c|c|c|c|c|}
\hline Case title & Case summary & $\begin{array}{l}\text { Alleged } \\
\text { breach(es) of } \\
\text { duty }\end{array}$ & $\begin{array}{l}\text { Alleged } \\
\text { damage(s) }\end{array}$ & $\begin{array}{l}\text { Legal } \\
\text { outcome }\end{array}$ & $\begin{array}{l}\text { Outcome } \\
\text { summary }\end{array}$ \\
\hline \multicolumn{6}{|l|}{ Circumcision } \\
\hline Ridgeway V. U.S. ${ }^{\text {O }}$ & $\begin{array}{l}\text { Plaintiff suffered a post-operative complication of } \\
\text { hematoma, ultimately requiring surgical evacuation. } \\
\text { He then developed "pain in the penis during erection } \\
\text { and inadequate erections due to shortened skin on } \\
\text { the left side of his penis". He underwent several skin } \\
\text { grafting procedures by a plastic surgeon. Plaintiff } \\
\text { alleged that the defendant deviated from standard of } \\
\text { care and acted negligently by removing too much } \\
\text { foreskin. }\end{array}$ & $\begin{array}{l}\text { Negligence, } \\
\text { procedural } \\
\text { error, } \\
\text { deviation } \\
\text { from standard } \\
\text { of care }\end{array}$ & $\begin{array}{l}\text { Erectile } \\
\text { dysfunction, } \\
\text { sexual } \\
\text { dysfunction, } \\
\text { genital pain } \\
\text { syndrome }\end{array}$ & $\begin{array}{l}\text { Favoring } \\
\text { defense }\end{array}$ & $\begin{array}{l}\text { Plaintiff failed to } \\
\text { establish any } \\
\text { deviation from the } \\
\text { standard of care } \\
\text { through review of } \\
\text { the operative } \\
\text { report and expert } \\
\text { testimony. }\end{array}$ \\
\hline Collado v. Plawner ${ }^{\mathrm{P}}$ & $\begin{array}{l}\text { Plaintiff suffered post-operative pain and swelling, } \\
\text { which was managed conservatively with } \\
\text { compression and pain medication by the surgeon. } \\
\text { Plaintiff ultimately underwent a second procedure to } \\
\text { remedy the swelling by a separate urologist. } \\
\text { Plaintiff claimed the defendant's negligence during } \\
\text { the initial surgery resulted in "incredible pain and } \\
\text { discomfort after the surgery and suffered permanent } \\
\text { loss of sensation in his penis, and consequent } \\
\text { continuing erectile dysfunction." Plaintiff also } \\
\text { alleged malpractice post-operatively "by failing to }\end{array}$ & $\begin{array}{l}\text { Procedural } \\
\text { error, } \\
\text { deviation } \\
\text { from standard } \\
\text { of care, } \\
\text { negligence }\end{array}$ & $\begin{array}{l}\text { Erectile } \\
\text { dysfunction, } \\
\text { genital pain } \\
\text { syndrome, loss } \\
\text { of sensation in } \\
\text { genitals }\end{array}$ & $\begin{array}{l}\text { Favoring } \\
\text { defense }\end{array}$ & $\begin{array}{l}\text { The jury } \\
\text { determined that the } \\
\text { defendant did } \\
\text { deviate from } \\
\text { accepted standards } \\
\text { of medical care } \\
\text { during the post- } \\
\text { operative care of } \\
\text { the plaintiff, } \\
\text { however, they felt } \\
\text { that this deviation }\end{array}$ \\
\hline
\end{tabular}




\begin{tabular}{|c|c|c|c|c|c|}
\hline & $\begin{array}{l}\text { take a more aggressive, investigatory approach to } \\
\text { [his] complaints of pain and lymphedema." }\end{array}$ & & & & $\begin{array}{l}\text { did not directly } \\
\text { result in the } \\
\text { damages (loss of } \\
\text { penile sensation, } \\
\text { erectile } \\
\text { dysfunction) } \\
\text { claimed by the } \\
\text { plaintiff. }\end{array}$ \\
\hline Jenkins v. Stirling ${ }^{Q}$ & $\begin{array}{l}\text { Plaintiff suffered pain following circumcision } \\
\text { prompting subsequent revision by a plastic surgeon. } \\
\text { Plaintiff alleged the defendant was "indifferent to } \\
\text { his medical needs". }\end{array}$ & $\begin{array}{l}\text { Deliberate } \\
\text { indifference }\end{array}$ & $\begin{array}{l}\text { Genital pain } \\
\text { syndrome }\end{array}$ & $\begin{array}{l}\text { Action } \\
\text { against the } \\
\text { defendant } \\
\text { dismissed }\end{array}$ & $\begin{array}{l}\text { Plaintiff failed to } \\
\text { provide evidence } \\
\text { that the defendant } \\
\text { "ever unreasonably } \\
\text { refused to treat } \\
\text { Plaintiff or to } \\
\text { provide care for } \\
\text { him". }\end{array}$ \\
\hline \multicolumn{6}{|l|}{ Epididymectomy } \\
\hline $\begin{array}{l}\text { Bellamy v. Mount } \\
\text { Vernon Hospital }^{\mathrm{R}}\end{array}$ & $\begin{array}{l}\text { The Plaintiff developed hypogonadism and } \\
\text { hypocortisolism post-operatively and claimed his } \\
\text { "weight loss, loss of appetite, erectile dysfunction, } \\
\text { inability to ejaculate, and potential infertility" was } \\
\text { the direct result of his epididymectomy. Plaintiff } \\
\text { alleged the defendant "purposely failed to fully } \\
\text { discuss and disclose all the possible risks of the } \\
\text { surgery, in particular the possible effects on his } \\
\text { hormone levels and the reproductive capability of } \\
\text { his left testicle," and "deliberately chose an inferior } \\
\text { method of treating his condition". }\end{array}$ & $\begin{array}{l}\text { Failure to } \\
\text { disclose } \\
\text { information, } \\
\text { failure to } \\
\text { achieve } \\
\text { informed } \\
\text { consent }\end{array}$ & $\begin{array}{l}\text { Erectile } \\
\text { dysfunction, } \\
\text { hypogonadism }\end{array}$ & $\begin{array}{l}\text { Favoring } \\
\text { defense; } \\
\text { summary } \\
\text { judgement } \\
\text { granted to } \\
\text { defendant on } \\
\text { all claims. }\end{array}$ & $\begin{array}{l}\text { Plaintiff was } \\
\text { unable to provide } \\
\text { conclusive } \\
\text { evidence that his } \\
\text { epididymectomy } \\
\text { was responsible } \\
\text { for the damages } \\
\text { claimed. He failed } \\
\text { to prove } \\
\text { "deliberate } \\
\text { indifference" of } \\
\text { the defendant, or } \\
\text { that the defendant } \\
\text { withheld }\end{array}$ \\
\hline
\end{tabular}




\begin{tabular}{|c|c|c|c|c|c|}
\hline & & & & & $\begin{array}{l}\text { information from } \\
\text { him. }\end{array}$ \\
\hline Primus v. Lee ${ }^{\mathrm{S}}$ & $\begin{array}{l}\text { Plaintiff underwent epididymectomy for benign } \\
\text { cyst. Plaintiff alleges that he and the defendant } \\
\text { "became involved in 'an unpleasant exchange,' } \\
\text { during which Defendant allegedly threatened to } \\
\text { remove Plaintiff's testicle if he continued to 'mess' } \\
\text { with Defendant." Post-operatively, the patient } \\
\text { claimed loss of the right testicle and resultant } \\
\text { erectile dysfunction, and asserted that "Defendant } \\
\text { intentionally and maliciously removed it during the } \\
\text { surgery." He alleged that the defendant exhibited a } \\
\text { "deliberate indifference" to his medical needs. }\end{array}$ & $\begin{array}{l}\text { Deviation } \\
\text { from standard } \\
\text { of care, } \\
\text { deliberate } \\
\text { indifference }\end{array}$ & Loss of testicle & $\begin{array}{l}\text { Favoring } \\
\text { defense; } \\
\text { summary } \\
\text { judgement } \\
\text { granted to } \\
\text { defendant on } \\
\text { all claims. }\end{array}$ & $\begin{array}{l}\text { Medical record } \\
\text { showed "ischemic } \\
\text { atrophy" of the } \\
\text { alleged lost } \\
\text { testicle, which was } \\
\text { confirmed on } \\
\text { ultrasound. Expert } \\
\text { testimony } \\
\text { confirmed this is a } \\
\text { known } \\
\text { complication of } \\
\text { the procedure. } \\
\text { Plaintiff failed to } \\
\text { show deviation } \\
\text { from standard of } \\
\text { care or deliberate } \\
\text { indifference. }\end{array}$ \\
\hline
\end{tabular}

${ }^{\mathrm{O}}$ Ridgeway v. U.S., Civ. No. 03-386-SLR (D. Del. Sep. 29, 2006). ${ }^{\mathrm{P} C o l l a d o ~ v . ~ P l a w n e r, ~} 2010$ N.Y. Slip Op. 32837 (N.Y. Sup. Ct. 2010$) .{ }^{\text {QJ Jenkins v. }}$ Stirling, No. 5:14-2711-RMG-KDW (D.S.C. Oct. 31, 2014). ${ }^{R}$ Bellamy v. Mount Vernon Hospital, 07 Civ. 1801 (SAS) (S.D.N.Y. Aug. 5, 2008).

SPrimus v. Lee, Civil Action No.: 4:07-911-PMD (D.S.C. Mar. 30, 2010).

\begin{tabular}{|c|c|c|c|c|c|}
\hline \multicolumn{6}{|c|}{ Table 1D. Description of cases in the study } \\
\hline Case title & Case summary & $\begin{array}{l}\text { Alleged } \\
\text { breach(es) of } \\
\text { duty }\end{array}$ & $\begin{array}{l}\text { Alleged } \\
\text { damage(s) }\end{array}$ & $\begin{array}{l}\text { Legal } \\
\text { outcome }\end{array}$ & $\begin{array}{l}\text { Outcome } \\
\text { summary }\end{array}$ \\
\hline \multicolumn{6}{|l|}{ Vasectomy } \\
\hline $\begin{array}{l}\text { Arroyo v. Univ. of Conn. } \\
\text { Health Ctr. }\end{array}$ & $\begin{array}{l}\text { Immediately following a vasectomy, Plaintiff } \\
\text { suffered pain that "continued, unabated, for several }\end{array}$ & $\begin{array}{l}\text { Procedural } \\
\text { error, }\end{array}$ & Loss of testicle & $\begin{array}{l}\text { Favoring } \\
\text { plaintiff }\end{array}$ & $\begin{array}{l}\text { The pathology } \\
\text { report confirmed a }\end{array}$ \\
\hline
\end{tabular}




\begin{tabular}{|c|c|c|c|c|c|}
\hline & $\begin{array}{l}\text { days", and, he was found to have a lack of blood } \\
\text { flow to the testicle on subsequent evaluation. He } \\
\text { ultimately underwent orchiectomy by a separate } \\
\text { urologist. Plaintiff alleged that the defendant } \\
\text { negligently performed the procedure, and that } \\
\text { "during the procedure Defendant failed to identify, } \\
\text { dissect and ligate the vas deferens, but instead he } \\
\text { incorrectly dissected and ligated surrounding } \\
\text { vascular structures thereby depriving, restricting } \\
\text { and severing blood flow to [Plaintiff's] left testicle." }\end{array}$ & $\begin{array}{l}\text { deviation } \\
\text { from standard } \\
\text { of care } \\
\text { resulting in } \\
\text { damage }\end{array}$ & & & $\begin{array}{l}\text { segment of vein } \\
\text { had been removed. } \\
\text { Expert testimony } \\
\text { opined that the } \\
\text { defendant likely } \\
\text { isolated and } \\
\text { severed a vein, } \\
\text { encountered } \\
\text { bleeding, and } \\
\text { subsequently } \\
\text { damaged the artery } \\
\text { with cauterization, } \\
\text { thus, it was ruled } \\
\text { that the defendant } \\
\text { deviated from the } \\
\text { standard of care. } \\
\text { The court awarded } \\
\text { Plaintiff } \$ 300,000 \\
\text { in noneconomic } \\
\text { damages. }\end{array}$ \\
\hline \multicolumn{6}{|c|}{ Penile skin debridement } \\
\hline Smith v. Rodillo ${ }^{\mathrm{U}}$ & $\begin{array}{l}\text { The defendant urologist failed to examine a patient } \\
\text { who met criteria for urologic evaluation by several } \\
\text { other physicians. Ultimately, this lead to a delayed } \\
\text { diagnosis of Fournier's gangrene by several days. } \\
\text { The patient underwent extensive debridement (by a } \\
\text { separate physician), including partial debridement } \\
\text { of penile skin and grafting, leading to scarring, loss } \\
\text { of genital sensation, and loss of sustained erection. }\end{array}$ & Negligence & $\begin{array}{l}\text { Erectile } \\
\text { dysfunction, } \\
\text { loss of } \\
\text { sensation of } \\
\text { genitals }\end{array}$ & $\begin{array}{l}\text { Favoring } \\
\text { defense, but } \\
\text { reversed } \\
\text { and } \\
\text { remanded } \\
\text { for a retrial }\end{array}$ & $\begin{array}{l}\text { In the initial } \\
\text { hearing, the court } \\
\text { found lack of } \\
\text { evidence for a } \\
\text { "physician-patient } \\
\text { relationship" and } \\
\text { thus favored the } \\
\text { defense. This was } \\
\text { appealed by the } \\
\text { plaintiff and a }\end{array}$ \\
\hline
\end{tabular}




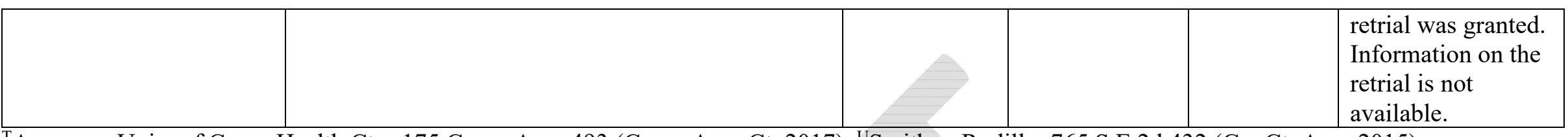

${ }^{\mathrm{T}}$ Arroyo v. Univ. of Conn. Health Ctr., 175 Conn. App. 493 (Conn. App. Ct. 2017). USmith v. Rodillo, 765 S.E.2d 432 (Ga. Ct. App. 2015).

\begin{tabular}{|l|l|}
\hline Table 2. Areas of body involved, $\mathbf{n}(\%)$ & $7(33 \%)$ \\
\hline Prostate & $7(33 \%)$ \\
\hline Penis & $3(14 \%)$ \\
\hline Urethra & $3(14 \%)$ \\
\hline Epididymis & $1(5 \%)$ \\
\hline Vas deferens & $1(5 \%)$ \\
\hline Inguinal region & \\
\hline
\end{tabular}

Percents were rounded to the nearest whole number, thus this adds up to

$104 \%$ based on above.

\begin{tabular}{|l|l|}
\hline Table 3. Primary alleged breaches of duty, $\mathbf{n}(\mathbf{\%})$ & $15(31 \%)$ \\
\hline Deviation from standard of care resulting in damage & $12(25 \%)$ \\
\hline Procedural error & $9(19 \%)$ \\
\hline Negligence & $3(6 \%)$ \\
\hline Failure to achieve informed consent & $3(6 \%)$ \\
\hline Deliberate indifference to medical needs & $3(6 \%)$ \\
\hline Overtreatment & $3(6 \%)$ \\
\hline Failure to disclose information &
\end{tabular}

Percents were rounded to the nearest whole number, thus this adds up to $99 \%$ based on above. 